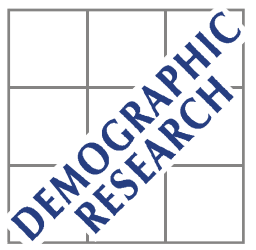

Demographic Research a free, expedited, online journal of peer-reviewed research and commentary in the population sciences published by the Max Planck Institute for Demographic Research Konrad-Zuse Str. 1, D-18057 Rostock · GERMANY www.demographic-research.org

DEMOGRAPHIC RESEARCH

VOLUME 22, ARTICLE 24, PAGES 733-770 PUBLISHED 27 APRIL 2010

http://www.demographic-research.org/Volumes/Vol22/24/

DOI: $10.4054 /$ DemRes.2010.22.24

Research Article

\title{
Trends in educational assortative marriage in China from 1970 to 2000
}

\section{Hongyun Han}

(C) 2010 Hongyun Han.

This open-access work is published under the terms of the Creative Commons Attribution NonCommercial License 2.0 Germany, which permits use, reproduction \& distribution in any medium for non-commercial purposes, provided the original author(s) and source are given credit.

See http:// creativecommons.org/licenses/by-nc/2.0/de/ 


\section{Table of Contents}

$\begin{array}{lll}1 & \text { Introduction } & 734\end{array}$

2 The changing context of educational assortative marriage in China 735

2.1 Educational expansion 735

$\begin{array}{lll}2.2 & \text { Economic returns on education } & 736\end{array}$

2.3 The changing context of marriage 737

2.4 Educational assortative marriage in China 738

3 Data and measurement $\quad 739$

$\begin{array}{lll}3.1 & \text { Data } & 739\end{array}$

$\begin{array}{lll}3.2 & \text { Measurement } & 740\end{array}$

$\begin{array}{lll}3.2 .1 & \text { First marriage } & 740\end{array}$

$\begin{array}{lll}3.2 .2 & \text { Rural and urban } & 741\end{array}$

$\begin{array}{lll}\text { 3.2.3 Educational attainment } & 741\end{array}$

$4 \quad$ Log-linear models $\quad 744$

$5 \quad$ Results 746

5.1 Trends in educational assortative marriage $\quad 746$

5.1.1 Homogamous marriages and the rural-urban division 746

$\begin{array}{lll}\text { 5.1.2 Heterogamous marriages and the rural-urban division } & 747\end{array}$

$\begin{array}{lll}5.2 & \text { Selection of models } & 748\end{array}$

$5.3 \quad$ Results of Log-linear models $\quad 752$

5.3.1 Estimated trends in educational homogamy at the national level 752

5.3.2 The rural-urban division in educational homogamy 753

5.3.3 Estimated trends in educational heterogamy 533

$\begin{array}{lll}5.4 & \text { Explanations of rising educational homogamy trends } & 760\end{array}$

$\begin{array}{lll}6 & \text { Summary and conclusion } & 761\end{array}$

7 Acknowledgements $\quad 763$

$\begin{array}{ll}\text { References } & 764\end{array}$

$\begin{array}{ll}\text { Appendix } 1 & 769\end{array}$

$\begin{array}{ll}\text { Appendix } 2 & 770\end{array}$ 


\title{
Trends in educational assortative marriage in China from 1970 to 2000
}

\author{
Hongyun Han ${ }^{1}$
}

\begin{abstract}
This research examines trends in educational assortative marriage in China among first marriages from 1970 to 2000, using data from the 2000 China Population Census and the 2001 Chinese Demographic Reproductive Health Survey. The results reveal decreasing educational homogamy rates from 1970 to 1980. However, the estimated odds of educational homogamy increase substantially between 1980 and 1995 and then grow at a slower pace in the late 1990s. Further, in urban areas, increasing rates of resemblance between spouses occur a decade earlier and at a higher level, compared to rural areas. Overall, the results indicate that senior high school graduates and college graduates in the late 1990s are less likely to marry those with less education than those in the 1970s in modern China.
\end{abstract}

\footnotetext{
${ }^{1}$ University of Wisconsin Madison. E-Mail: hhan@ssc.wisc.edu.
} 


\section{Introduction}

Because marriage patterns are not only indicators of social openness, but are also a source of social and intergenerational inequality, scholars of social mobility pay a great deal of attention to how individuals partner in marriage (Kalmijn 1991, 1998; Mare 1991; Fernandez, Guner and Knowles 2005; Ermisch, Francesconi and Siedler 2006). Scholars posit that individuals have a strong tendency to marry those who share similar levels of education, for three reasons. First, educational institutions are critical marriage markets in which young adults mingle (Mare 1991). Second, education is an important predictor of occupational success and individuals tend to select a partner who offers them the most economic prosperity (Smits, Ultee and Lammers 1998, 2000; Lewis and Oppenheimer 2000). Third, education is an approximator of shared cultural interests and lifestyles (Kalmijn 1991, 1998). China provides a unique context in which to examine these theoretical arguments, because educational expansion, marriage reform, and the rising economic value of education have reshaped martial preferences during the process of modernization. However, studies of educational homogamy in China at the national and regional levels after the 1980s are scarce (Smits, Ultee and Lammers 2000; Raymo and Xie 2000; Xu, Ji and Tung 2000; Smits 2003; Smits and Park 2009; Song 2009).

This study advances the existing literature on educational homogamy in China by studying national-level trends through 2000 and examining rural-urban differences. I use two large, nationally representative datasets to examine the patterns of educational assortative marriage for recently married couples. I use log-linear models to measure the social distances among different educational groups. I demonstrate that in China after the 1980s, individuals increasingly married others similar to them with respect to education. Furthermore, the degree of educational homogamy was larger and the increase in homogamy began earlier in urban areas, as compared to rural areas. These findings about rising levels of educational homogamy support the status attainment hypothesis, which states that the higher the economic value of education, the greater the degree of educational homogamy. The paper proceeds as follows: First, I review the changing forces influencing marriage patterns in China to derive my hypotheses. Next, I describe the data and methods employed. I then present the model specification and my analytical results. Finally, I summarize the findings and conclude the paper. 


\section{The changing context of educational assortative marriage in China}

Unprecedented economic growth and radical social reforms have characterized China's modernization. The Gross Domestic Product (GDP) per capita in China increased from US $\$ 100$ to US $\$ 1000$ between 1978 and 2000 (IMF 2000). ${ }^{2}$ Centrally controlled reform and a striking division between rural and urban regions are two features that distinguish China from other developing countries. In the following section, I review the factors influencing changes in the patterns of educational assortative marriage, including educational expansion, increasing economic returns on education, and demographic changes in marriage markets.

\subsection{Educational expansion}

Massive educational expansion after 1978 dramatically reshaped the educational distribution in China. State government in China monopolizes the allocation of educational opportunities (Zhou, Moen and Tuma 1998). In 1978, after a ten-year setback due to the Cultural Revolution (1966-1976), the state government launched a nationwide educational reform (Deng and Treiman 1997). The educational reform included two major components: implementing compulsory completion of nine years of education and reopening post-secondary education institutions. Figure 1 illustrates the effects of this massive educational expansion: from 1970 to 2000 the mean years of schooling increased for both men and women, regardless of household registration status. $^{3}$

Despite similar increases in the average educational level in urban and rural areas, urban areas stand out in two respects. First, in urban areas, the growth in education was concentrated at the college level, with the number of colleges more than doubling and the enrollment of students more than tripling by the end of the 1980s (Shu 2004). In contrast, in rural areas, increasing educational attainment resulted mainly in individuals completing junior high school (i.e., completing nine years of school). Second, the largest change in rural areas occurred between 1970 and 1985, and educational

\footnotetext{
${ }^{2}$ IMF's World Economic Outlook data; all values of GDP are in 2000 US dollars.

${ }^{3}$ Since the 1950s, the Chinese household registration system ("hukou") has classified citizens according to both place of residence and eligibility for certain socioeconomic benefits (the latter via designation as either "agricultural" or "non-agricultural" residents). Rural and urban hukou holders were usually designated agricultural and non-agricultural statuses, respectively. The main purposes of the hukou system are: resource distribution, migration control, and the monitoring of targeted groups of people (Wang 2005).
} 
attainment stalled thereafter for both men and women. In urban areas, the rising educational attainment continued gradually in the late 1990s, mainly due to college expansion.

Figure 1: Mean years of schooling for women and men: China, 1970-2000

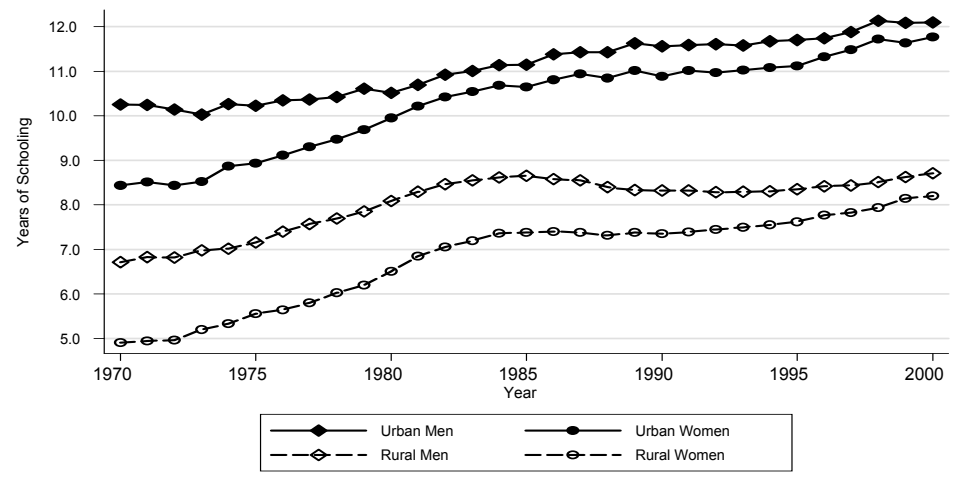

Source: 2000 China Population Census and 2001 Demographic Reproductive Health Survey

\subsection{Economic returns on education}

Increasing economic returns on education are a direct result of the reform of China's reward system implemented after 1978. As China was transformed from a centrally planned economic system to a market-based system, economic rewards began to shift from political capital to entrepreneurship and education (Nee 1989, 1991; Qian 2000; Zhang et al. 2005; Zhao and Zhou 2007). A host of studies have shown that the return on schooling increased between 1978 and 2001 (Nee 1989, 1991; Nee and Matthews 1996; Bian and Logan 1996; Zhou 2000; Bian 2002; Shu and Bian 2003). For example, in both rural and urban areas the economic return on education during the Cultural Revolution (1966-1976) was close to zero (Li and Zhang 1998; Zhang, Liu and Yung 2007). The schooling return rate rose to $2.5 \%{ }^{4}$ in the early $1980 \mathrm{~s}$, reached $4 \%$ in the early 1990s, and spiked to $10 \%$ in 2001 (Zhao and Zhou 2007, Zhang et al. 2005). Furthermore, rewards for education went primarily to the highly educated population

\footnotetext{
${ }^{4}$ The schooling return rate of $2.5 \%$ indicates that an individual's income tends to increase $2.5 \%$ with each additional year of school.
} 
and thus widened the degree of earning inequality across educational strata. In the late 1990s college graduates earned 50\% more than high school graduates, and high school graduates earned $20 \%$ more than those with less than six years of schooling (Zhao and Zhou 2007).

The increasing economic value of education was complicated by differences between rural and urban areas and by the persistent economic returns on political capital (Xie and Hannum 1996; Walder 1996, 2002; Li and Walder 2001; Hauser and Xie 2005). First, the economic prospects of education were relatively low for individuals living in rural areas because rewards were contingent on migration and nonfarm employment. $\mathrm{Li}$ and Zhang (1998) reported a 3.3\% increase in income for household farming in 1990. Most of the schooling returns came from employment in the private sector and the migration of workers from rural to urban areas after 1985 (Wei et al. 1999; Yang 1997; Zhao 1997, 1999). Second, membership in the communist party was a prerequisite for lucrative and secure jobs (Walder 1996; Xie and Hannum 1996; Hauser and Xie 2005). Therefore, studies of social mobility in China suggest that education and party membership have been the competing forces influencing the economic prospects and social status of individuals as China has undergone notable changes in social structure.

\subsection{The changing context of marriage}

Substantial demographic shifts accompanied China's remarkable educational expansion and increasing economic returns on education between 1970 and 2000. First, as arranged marriages declined, young people were more likely to meet potential partners at school, in the workplace and through dating agencies (Xu and Whyte 1990; Pochagina 2004). Compared to individuals in earlier eras, Chinese men and women were more likely to choose their spouse based upon age, appearance, income, and educational level rather than by parental socioeconomic status (Xia and Zhou 2003; Pochagina 2004). Second, young adults began to delay or forgo marriage. In 1980 a new marriage law set twenty as the minimum legal age of marriage for women and twenty-two for men (Diamant 2000). Figure 2 shows the parallel increases in the median age at first marriage for men and women in China using data from the sample in this study. Between 1970 and 2000, the median age at first marriage for rural men increased from 23 to 25 ; for rural women the median age grew from 20 to 23 . The trend of late marriage was more salient in urban areas, in which the median age at first marriage grew from 25 to 27 for men and from 22 to 25 for women. The decrease in age at first marriage right after 1980 reflected the lowered age at first marriage modified in the 1980 Marriage Law. In addition, the singulate mean age at marriage (SMAM) 
showed a similar increase during the period between 1990 and 2000 (Goodkind and Branch 2006). In short, the steady increase in the median age at first marriage during the mid-1980s and the late 1990s may be associated with increasing educational attainment for both men and women.

Figure 2: Median ages at first marriage for women and men: China, 1970-2000

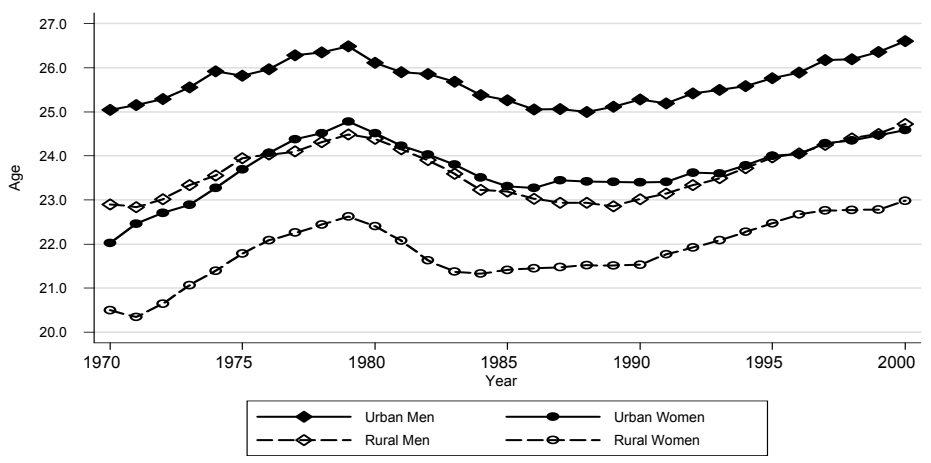

Source: 2000 China Population Census and 2001 Demographic Reproductive Health Survey.

\subsection{Educational assortative marriage in China}

Past research on the effects of economic development on educational assortative marriage has been cross-national and comparative, treating China as one of the Eastern Asian countries (Smits, Ultee and Lammers 1998; Raymo and Xie 2000; Smits and Park 2009). These studies also focused on specific areas of China and used data from relatively small samples (Xu, Ji and Tung 2000; Smits 2003; Song 2009). In general, the comparative studies found that educational homogamy decreased in China from the early 1970s to the early 1990s (Raymo and Xie 2000; Smits, Ultee and Lammers 2000; Smits and Park 2009). However, no study has examined Chinese national trends in educational homogamy beyond the early 1990s.

Studies using non-nationally representative data have provided inconsistent evidence about trends in educational homogamy in the 1980s. Smits (2003) identified declining educational homogamy rates among cohorts with postsecondary education in China. Song (2009) found a higher degree of homogamy among the 1977-1994 marriage cohorts than among the 1966-1976 cohorts. Yet, Xu and colleagues (2000) found no statistically significant changes in educational and status homogamy in two 
urban areas from the early 1950 s to the late 1980 s. Further, past studies have not revealed whether urban and rural areas showed similar patterns, despite of the persisting rural-urban division in the education and reward systems (Hannum 1999; Hannum, Wang and Adams 2008). In short, studies on Chinese national-level trends and regional variations in educational homogamy after the 1990s remain scarce.

In summary, I derive the following hypotheses based on prior review of the primary forces affecting marriage patterns:

1. Educational homogamy increased after 1980 as individuals placed greater value on education and expected economic returns in choosing a spouse.

2. Individuals with a higher level of education were less likely to marry those with less education in the 1990s than in the 1970s, because economic returns on education created a greater distinction between high school and college graduates compared to those within the lower educational strata.

\section{Data and measurement}

\subsection{Data}

I used data from the 2000 China Population Census (2000 Census) and the 2001 Demographic Reproductive Health Survey (2001 DRHS) to examine trends in educational assortative marriage from 1970 to 2000. The data from the 2000 Census (I use a $0.1 \%$ sample) was collected by the National Bureau of Statistics in 1999. The survey provided information on each household member's gender, date of birth, marital status, date of first marriage (year and month), current level of educational attainment, ${ }^{5}$ occupation, and household registration status. I used a sample of women age 15 to 49 to obtain data comparable to that from the 2001 DRHS. I also used information on the respondent's date of first marriage to pair wives and husbands within a single household because one household may include more than one married couple. ${ }^{6}$

\footnotetext{
${ }^{5}$ The current level of educational attainment is used as a proxy for educational attainment at the date of first marriage, since very few individuals pursue further education after marriage in China.

${ }^{6}$ For households with more than one married couple, the category for the relationship to head of household in the 2000 Census is defined as "sons and daughters," and does not differentiate daughters-in-law or sons-inlaw from daughters or sons. Therefore, it is possible to pair his own son with his own daughter if an older head of household lives with his adult children. To avoid this error, I take three steps to match couples: (1) I select people who are in their first marriage, (2) I compare the dates of the first marriage, and (3) I keep only couples for whom both dates of first marriage are in the same month and year.
} 
The 2001 DRHS was a nationally representative dataset with a sample of 39,586 women age 15 to 49 ; it was the latest survey in a series of fertility surveys conducted by the State Fertility Planning Commission (SFPC). The survey samples were drawn from approximately 180,000 individuals in sampled households. Using all women of reproductive age in sampled households as a new sampling frame, each province sampled women proportionally based on their distribution across provinces in the country. The individual-level questionnaire included the following respondent information: date of birth, ethnic group, highest educational degree attained, marital status, date of first marriage, and household registration status, as well as the husband's ethnicity and educational attainment.

For each dataset, I examined six marriage cohorts classified by the date of first marriage. The six marriage cohorts are: 1970-1974, 1975-1979, 1980-1984, 1985-1989, 1990-1994 and 1995-2001. I grouped the six marriage cohorts in a way that reflect changes in educational expansion, economic returns on education, and changing marriage markets. For instance, couples who married between January 1, 1970 and December 31, 1974 (i.e., the first marriage cohort) were married before the massive educational expansion, at a time when economic returns on education were extremely low. The median number of years married among the 1980-1984 cohort was two years higher than the previous cohort, reflecting the strict implementation of the minimum age at first marriage stipulated by the 1980 Marriage Law. The marriage cohorts of 1990-1994 were composed of couples who delayed marriage and benefited from educational expansion and rising schooling returns. To maximize sample size, I pooled the data from the 2000 Census and the 2001 DRHS in my analysis. The pooled data yielded a total sample of 235,075 first marriages. The urban sample included 60,770 first marriages, and the rural sample included 176,395 first marriages. The detailed numbers of marriages for each data source are presented in Appendix 1.

\subsection{Measurement}

\subsubsection{First marriage}

One approach to examining trends in educational assortative marriage is to use crosssectional marriage data gathered from multiple birth cohorts (i.e., groups of married people of similar ages), in other words, data from prevailing marriages. However, variation in marriage timing, divorce rates, and increases in education after marriage may all affect the degree of resemblance between spouses in a cohort (Schwartz and Mare 2003). Using data from first marriages can lessen these biases (Kalmijin 1991, 1998; Mare 1991; Qian and Preston 1993; Qian 1998; Raymo and Xie 2000). 
Therefore, first marriage is an appropriate unit of analysis for identifying the effects of historical changes on who marries whom (Raymo and Xie 2000). In addition, the data on first marriages are clearly more accurate than data on prevailing marriages for testing the above hypotheses about the effects of modernization, all other factors being equal (Smits, Ultee and Lammers 2000). Therefore, I used data drawn from a sample of individuals in their first marriage.

\subsubsection{Rural and urban}

Household registration status is the salient marker of social status in contemporary China (Wu and Treiman 2004). State education and economic policies are applied according to household registration status. Therefore, I distinguished between the rural sample and the urban sample in accordance with both husband's and wife's current household registration status at the time of the survey (2000 Census and 2001 DRHS). A couple was classified as urban if both the husband's and wife's current household registration status was urban at the date of survey. This definition was based on the assumption that the couple's household registration status remained the same between the date of first marriage and the date of the survey, as there was no retrospective information on the household registration status at the time of first marriage. ${ }^{7}$ In this study, $99.5 \%$ of couples shared the same household registration status. Thus, I excluded the remaining $0.5 \%$ of couples whose household registration status did not match.

\subsubsection{Educational attainment}

Educational attainment data was collected via similar questions in the 2000 Census and 2001 DRHS; the question asked the respondents to report their current educational level. Therefore, the level of current educational attainment used in my study is not the exact educational attainment at the date of first marriage. However, I believe the current level of education approximates educational attainment at the date of first marriage because increases in educational level after first marriage were quite rare among the earlier marriage cohorts, and the latest marriage cohorts did not have enough time to

\footnotetext{
${ }^{7}$ This assumption is reasonable for two reasons. First, upgrading household registration status is limited to joining the army, enrolling in college or joining a state-owned company, so migration workers seldom change their household registration status. Changing household registration status from rural to urban was formidable as there was almost no migration (Wu and Treiman 2004). Second, migration workers still find spouses in rural areas, and migrant wives' destinations are affluent rural areas, instead of cities (Fan and Huang 1998).
} 
complete educational upgrades after marriage. Therefore, I feel confident using the current educational attainment to examine the trends of educational assortative marriage.

I categorized educational attainment into four groups for all respondents. ${ }^{8}$ However, the educational categories are different for those in the urban sample compared to those in the national and rural samples, based on distinctive educational distributions. In urban areas, the four educational categories were elementary school or less ( $<=6$ year of schooling), junior high school ( $7-9$ years of schooling), senior high school (10-12 years of schooling) $)^{9}$ and college and up ( $>=13$ years of schooling). ${ }^{10}$ In the rural and national samples, the four educational categories were illiterate ${ }^{11}(<=1$ year of schooling), elementary school (2-6 years of schooling), junior high school (7-9 years of schooling) and senior high school and up ( $>=10$ years of schooling).

The marginal percentages distributions in Table 1 illustrate the changes in educational attainment for husbands and wives in this study. In general, the educational distribution changed substantially for both women and men. By 2000, more than twothirds of rural women and three-quarters of rural men graduated from high school, while a high school education was nearly universal for urban couples. The overall rising rate of educational attainment was driven primarily by a substantial increase in high school graduates and a decrease in the number of individuals with less than an elementary school education. In rural areas, the percentage of husbands graduating from junior high school grew from $32 \%$ to $67 \%$, while the percentage of wives graduating from junior high school expanded from $11 \%$ to $58 \%$. In urban areas, the percentage of individuals completing senior high school among men increased from $25 \%$ to $38 \%$, whereas this percentage nearly doubled among women, reaching $40 \%$ in 2000 . In contrast, the percentage of couples attaining a college degree increased only in urban areas, rising from $18 \%$ to $31 \%$ for men and from $6 \%$ to $24 \%$ for women in these areas. Overall, husbands have achieved higher levels of education than wives within each marriage cohort.

\footnotetext{
${ }^{8}$ There are nine educational categories in the 2000 Census, and five educational categories in the 2001 DRHS. I collapse the nine categories into four, in order to make the data from the two surveys parallel. 9 "Senior high school" includes "Senior high school" and "Vocational high school" in the 2000 Census. ${ }^{10}$ I grouped "College," "University" and "Graduate" in the 2000 Census into the single education category "College and Up," which is equivalent to "College and Up" in the 2001 DRHS. Approximately 8 percent of the sampled women age 15 to 49 belong in this category in both the 2000 Census and the 2001 DRHS.

${ }^{11}$ I grouped "No schooling" and "Recognize few words" into the category "Illiterate" in the 2000 Census; this category is equivalent to "Illiterate or recognize few words" in the 2001 DRHS. Approximately 14 percent of women age 15 to 49 were illiterate in 2000 according to the 2000 Census data.
} 
Table 1: Percentage distribution of educational attainment for wives and husbands from 1970 to 2001: China

\begin{tabular}{|c|c|c|c|c|c|c|c|c|c|c|c|}
\hline \multirow{3}{*}{$\begin{array}{l}\text { Husband's } \\
\text { education }\end{array}$} & \multicolumn{6}{|c|}{ Rural } & \multicolumn{5}{|c|}{ Urban } \\
\hline & \multirow[b]{2}{*}{ Illiterate } & \multirow[b]{2}{*}{ Primary } & \multicolumn{2}{|c|}{ Wife's education } & \multirow[b]{2}{*}{ Total } & \multirow{2}{*}{$\begin{array}{l}\text { Husband's } \\
\text { education }\end{array}$} & \multicolumn{5}{|c|}{ Wife's education } \\
\hline & & & $\begin{array}{c}\text { Jr. High } \\
\text { School }\end{array}$ & $\begin{array}{l}\text { Sr. High } \\
\text { School+ }\end{array}$ & & & $\begin{array}{c}< \\
\text { Primary }\end{array}$ & $\begin{array}{l}\text { Jr. High } \\
\text { School }\end{array}$ & $\begin{array}{l}\text { Sr. High } \\
\text { School }\end{array}$ & $\begin{array}{c}\text { College } \\
+\end{array}$ & Total \\
\hline$\overline{1970-1974}$ & & & & & & $1970-1974$ & & & & & \\
\hline Illiterate & 5.82 & 1.35 & 0.10 & 0.02 & 7.29 & $<$ Primary & 15.07 & 5.02 & 1.13 & 0.11 & 21.34 \\
\hline Primary & 15.27 & 38.87 & 2.44 & 0.15 & 56.72 & Jr. High School & 12.94 & 17.23 & 3.82 & 0.76 & 34.74 \\
\hline Jr. High School & 5.16 & 18.72 & 7.69 & 0.25 & 31.81 & Sr. High School & 6.98 & 9.67 & 7.56 & 1.49 & 25.69 \\
\hline Sr. High School+ & 0.76 & 2.39 & 0.84 & 0.18 & 4.18 & College+ & 2.29 & 5.73 & 6.02 & 4.18 & 18.23 \\
\hline \multirow[t]{2}{*}{ Total } & 27.01 & 61.34 & 11.06 & 0.59 & 100.0 & Total & 37.27 & 37.65 & 18.54 & 6.53 & 100.0 \\
\hline & & & & & 17,122 & & & & & & 4,499 \\
\hline $1975-1979$ & & & & & & $1975-1979$ & & & & & \\
\hline Illiterate & 3.84 & 0.94 & 0.15 & 0.04 & 4.98 & $<$ Primary & 7.89 & 4.00 & 1.08 & 0.09 & 13.06 \\
\hline Primary & 10.07 & 31.37 & 3.79 & 0.47 & 45.69 & Jr. High School & 9.60 & 25.36 & 6.37 & 1.09 & 42.42 \\
\hline Jr. High School & 5.26 & 20.84 & 12.88 & 0.92 & 39.90 & Sr. High School & 4.15 & 10.35 & 9.51 & 1.88 & 25.89 \\
\hline Sr. High School+ & 1.46 & 4.05 & 2.82 & 1.10 & 9.43 & College+ & 1.22 & 5.78 & 6.03 & 5.61 & 18.64 \\
\hline \multirow[t]{2}{*}{ Total } & 20.63 & 57.20 & 19.64 & 2.53 & 100.0 & Total & 22.86 & 45.49 & 22.99 & 8.67 & 100.0 \\
\hline & & & & & 23,582 & & & & & & 6,969 \\
\hline 1980-1984 & & & & & & $1980-1984$ & & & & & \\
\hline Illiterate & 1.99 & 0.71 & 0.23 & 0.04 & 2.97 & $<$ Primary & 3.76 & 2.50 & 1.18 & 0.05 & 7.50 \\
\hline Primary & 5.07 & 19.52 & 4.89 & 0.86 & 30.34 & Jr. High School & 4.50 & 23.53 & 11.31 & 0.86 & 40.20 \\
\hline Jr. High School & 3.88 & 20.08 & 22.62 & 3.03 & 49.61 & Sr. High School & 1.96 & 11.12 & 19.37 & 1.88 & 34.33 \\
\hline Sr. High School+ & 1.29 & 5.62 & 7.02 & 3.15 & 17.08 & College+ & 0.40 & 3.17 & 8.59 & 5.81 & 17.97 \\
\hline \multirow[t]{2}{*}{ Total } & 12.24 & 45.93 & 34.76 & 7.08 & 100.0 & Total & 10.61 & 40.33 & 40.46 & 8.60 & 100.0 \\
\hline & & & & & 31,908 & & & & & & 12,580 \\
\hline 1985-1989 & & & & & & $1985-1989$ & & & & & \\
\hline Illiterate & 0.99 & 0.39 & 0.11 & 0.02 & 1.50 & $<$ Primary & 1.71 & 1.54 & 0.48 & 0.03 & 3.76 \\
\hline Primary & 3.09 & 17.08 & 5.19 & 0.33 & 25.69 & Jr. High School & 3.39 & 22.16 & 8.82 & 0.75 & 35.12 \\
\hline Jr. High School & 2.56 & 22.67 & 33.87 & 2.06 & 61.16 & Sr. High School & 1.18 & 12.72 & 20.91 & 2.83 & 37.63 \\
\hline Sr. High School+ & 0.40 & 3.15 & 6.36 & 1.74 & 11.65 & College+ & 0.15 & 2.54 & 9.84 & 10.96 & 23.49 \\
\hline \multirow[t]{2}{*}{ Total } & 7.04 & 43.28 & 45.53 & 4.14 & 100.0 & Total & 6.43 & 38.95 & 40.05 & 14.58 & 100.0 \\
\hline & & & & & 39,446 & & & & & & 13,008 \\
\hline 1990-1994 & & & & & & 1990-1994 & & & & & \\
\hline Illiterate & 1.02 & 0.35 & 0.09 & 0.00 & 1.46 & $<$ Primary & 1.40 & 1.43 & 0.23 & 0.02 & 3.07 \\
\hline Primary & 2.84 & 18.82 & 6.08 & 0.25 & 27.98 & Jr. High School & 2.94 & 23.33 & 7.57 & 0.95 & 34.79 \\
\hline Jr. High School & 1.86 & 21.92 & 38.27 & 1.57 & 63.61 & Sr. High School & 1.05 & 12.08 & 17.48 & 3.56 & 34.17 \\
\hline Sr. High School+ & 0.14 & 1.66 & 4.00 & 1.15 & 6.95 & College+ & 0.20 & 2.98 & 9.75 & 15.04 & 27.97 \\
\hline \multirow[t]{2}{*}{ Total } & 5.86 & 42.75 & 48.44 & 2.96 & 100.0 & Total & 5.59 & 39.82 & 35.03 & 19.56 & 100.0 \\
\hline & & & & & 33,543 & & & & & & 11,074 \\
\hline $1995-2001$ & & & & & & $1995-2001$ & & & & & \\
\hline Illiterate & 0.73 & 0.29 & 0.11 & 0.01 & 1.14 & $<$ Primary & 0.69 & 1.00 & 0.21 & 0.04 & 1.94 \\
\hline Primary & 2.07 & 14.45 & 6.50 & 0.34 & 23.36 & Jr. High School & 1.46 & 18.75 & 7.31 & 0.87 & 28.39 \\
\hline Jr. High School & 1.35 & 17.54 & 46.39 & 2.36 & 67.64 & Sr. High School & 0.42 & 11.63 & 20.96 & 5.21 & 38.22 \\
\hline Sr. High School+ & 0.09 & 1.10 & 4.77 & 1.90 & 7.86 & College+ & 0.06 & 2.47 & 10.87 & 18.05 & 31.44 \\
\hline \multirow[t]{2}{*}{ Total } & 4.24 & 33.38 & 57.77 & 4.61 & 100.0 & Total & 2.63 & 33.85 & 39.36 & 24.17 & 100.0 \\
\hline & & & & & 29,794 & & & & & & 11,640 \\
\hline
\end{tabular}




\section{Log-linear models}

This study uses log-linear models to analyze contingency tables in order to describe changes in patterns of educational assortative mating. Log-linear models provide estimates of the changing association between couples' educational characteristics, controlling for shifts in their marginal distributions (Schwartz and Mare 2005). Homogamy models measure general trends in educational homogamy and crossing models reveal which educational differences between prospective spouses are serious barriers to intermarriage and which are relatively permeable (Mare 1991). I produced a contingency table with 192 cells $(6 \times 4 \times 4 \times 2)$ by cross-tabulating husbands' education with wives' education for the six marriage cohorts and two data sources. Each cell represents the number of first marriages between individuals with specific levels of education within a given marriage cohort and data source. The diagonal cells in the contingency table represent the homogamous marriages, while the off-diagonal cells represent the heterogamous marriages.

In order to estimate the log-linear models, I started with a baseline model, allowing three-way interactions among couples' education by marriage cohort and data source:

$$
\log F_{i j k l}=\beta_{0}+\beta_{i}^{H}+\beta_{j}^{W}+\beta_{k}^{C}+\beta_{l}^{D}+\beta_{i k}^{H C}+\beta_{j k}^{W C}+\beta_{i j}^{H W}+\beta_{i l}^{H D}+\beta_{j l}^{W D}+\beta_{i k l}^{H C D}+\beta_{j k l}^{W C D}+\beta_{i j l}^{H W D}
$$

where $F_{i j k l}$ is the expected frequency for cell $i j k l$ in the contingency table; $H, W, C$, and $D$ are the variables; ${ }^{12}$ and $i, j, k$, and $l$ are the categories within the variables $H, W, C$, and $D . \beta_{0}$ is the grand mean of the natural $\log$ of the expected frequencies; $\beta_{i}^{H}, \beta_{j}^{W}$, $\beta_{k}^{C}$, and $\beta_{l}^{D}$ are the main effects of husband's education, wife's education, cohort, and data source, respectively. $\beta_{i k}^{H C}$ and $\beta_{j k}^{W C}$ are the interactions between marriage cohorts and husband's and wife's education, respectively. $\beta_{i l}^{H D}$ and $\beta_{j l}^{W D}$ are the interactions between data source and husband's and wife's education. $\beta_{i j l}^{H W D}$ is the interaction between couples' education and data source.

In order to model the trends in educational homogamy, I added a homogamy parameter to the baseline model. This homogamy parameter is a $4 \times 4$ matrix with " 1 " in the diagonal cells and " 0 " in all other cells. Larger values in homogamy parameters

${ }^{12} H$ : Husband's education, $i=1-4 ; W$ : Wife's education, $j=1-4$; $C$ : Marriage cohorts, $k=1-6 ; D$ : Data sources, $l=0,1$. 
indicate that couples are more likely to marry those with similar levels of educational attainment.

$$
\begin{aligned}
& \log F_{i j k l}= \\
& \beta_{0}+\beta_{i}^{H}+\beta_{j}^{W}+\beta_{k}^{C}+\beta_{l}^{D}+\beta_{i k}^{H C}+\beta_{j k}^{W C}+\beta_{i j}^{H W}+\beta_{i l}^{H D}+\beta_{j l}^{W D}+\beta_{i k l}^{H C D}+\beta_{j k l}^{W C D}+\beta_{i j l}^{H W D}+\beta_{O}^{C O}
\end{aligned}
$$

where $\beta_{O}^{C O}$ allows the homogamy parameter to vary by cohort.

I specified crossing odds models in accordance with the clear applications of crossing odds models in Mare (1991) and Schwartz and Mare (2005). A series of crossing parameters were then added to the baseline model.

$$
\begin{aligned}
& \log F_{i j k l}= \\
& \beta_{0}+\beta_{i}^{H}+\beta_{j}^{W}+\beta_{k}^{C}+\beta_{l}^{D}+\beta_{i k}^{H C}+\beta_{j k}^{W C}+\beta_{i j}^{H W}+\beta_{i l}^{H D}+\beta_{j l}^{W D}+\beta_{i k l}^{H C D}+\beta_{j k l}^{W C D}+\beta_{i j l}^{H W D}+\beta_{k p}^{C X}
\end{aligned}
$$

where $X$ represents the crossing parameters, and $\beta_{k p}^{C X}$ represents the odds of crossing educational barriers.

The odds of crossing the several barriers between men and women from different educational strata (i.e., marrying across groups) are a function of the $\beta$ parameters (Mare 1991). Controlling for the marginal distribution of spouses' education, the odds that a marriage observed in cohort $k$ crosses barrier $\mathrm{p}$ is $\lambda_{k p}=\exp \left(\beta_{p}^{X}+\beta_{k p}^{C X}\right)$. Table 2 presents the contribution of each of these odds of intermarriage to the expected number of marriages. The crossing parameters indicate that couples with a greater distance between education levels have more barriers to cross. The estimated change in crossing parameters may provide evidence for variations in the rigidity of barriers across educational distribution over time.

Table 2: Parameters for crossings effects on educational assortative marriage

\begin{tabular}{lcccc}
\hline Husband's education & \multicolumn{4}{l}{ Wife's education } \\
\hline \multirow{2}{*}{ Illiterate } & Illiterate & Elementary & Junior high school & Senior high school+ \\
\cline { 2 - 5 } Elementary & 1 & $\lambda_{2}$ & $\lambda_{2} \lambda_{3}$ & $\lambda_{2} \lambda_{3} \lambda_{4}$ \\
Junior high school & $\lambda_{2}$ & 1 & $\lambda_{3}$ & $\lambda_{3} \lambda_{4}$ \\
Senior high school+ & $\lambda_{2} \lambda_{3}$ & $\lambda_{3}$ & 1 & $\lambda_{4}$ \\
\hline
\end{tabular}

Source: Mare (1991). 


\section{Results}

In this section, I first present a descriptive analysis of the trends in educational homogamy and heterogamy. I then describe the model selection process, and finally I summarize the estimated trends in educational homogamy and intermarriages yielded from the best fit models.

\subsection{Trends in educational assortative marriage}

\subsubsection{Homogamous marriages and the rural-urban division}

Figure 3 shows the changes in the percentage of educational assortative marriages for Chinese women age 15 to 49 married between 1970 and $2001 .^{13}$ The percentage of all marriages that were homogamous marriages first dropped and then climbed gradually between the 1980-1984 cohort and the 1995-2001 cohort. Among couples married in $1970-1974,50.2 \%$ of wives shared the same level of educational attainment as their husbands. This percentage decreased to $49.2 \%$ for couples married between 1980 and 1984. Yet, the percentage of couples with the same years of schooling increased monotonically from $50 \%$ to $65 \%$ between the 1985-1989 marriage cohort and the 1995 2000 cohort. In short, at the national level there has been an overall 15-point increase in the percentage of educational homogamy among these six marriage cohorts from 1970 to 2000 .

Panel B in Figure 3 illustrates the ways in which homogamy trends differed in urban and rural areas during this time period. The pattern of homogamy in rural areas has three distinctive features. First, the percentage of homogamous marriages among the rural sample of wives declined from $54 \%$ to $47 \%$ between 1970 and 1980 , while the percentage among the urban sample increased from $44 \%$ to $54 \%$. These contrasting trends for rural and urban wives offset each other, which explain the relatively stable trend at the national level. Second, between 1980 and 2001 the increases in the homogamy rate among wives in the rural sample were around four points larger than the increases for those in urban sample. Third, more than $80 \%$ of homogamous marriages in rural areas are between couples with less than a senior high school education, compared to less than $20 \%$ in urban areas. In addition, in rural areas the largest increase in homogamy rates was the six-fold increase in homogamous marriages

\footnotetext{
${ }^{13}$ Hypogamous marriages refer to the marriages in which wives' education exceeds their husbands' education. Hypergamous marriages refer to the marriages in which husbands' education surpasses their wives' education.
} 
between junior high school graduates, while the largest increase in the urban sample was marriages among high school and college graduates. In short, the trends in homogamous marriage for the rural sample have distinctively different features from the patterns for the urban sample.

\subsubsection{Heterogamous marriages and the rural-urban division}

Panel A of Figure 3 illustrates the decreasing percentage of hypergamous marriages (i.e., wives marrying husbands with more education) among total marriages from 1970 to 2001. Among all marriages from the early 1970 s, $45 \%$ of wives married husbands with higher levels of education, yet only $24 \%$ of wives followed this pattern in the late 1990s. Although the percentage of wives marrying husbands with lower levels of education continued to rise after the early 1980 s, the increase was not sufficient to counteract the dropping heterogamous marriage rates caused by fewer wives marrying husbands with a higher education level.

Using the number of educational barriers crossed to investigate the changes in the percentage of heterogamous marriages, Panel A of Figure 4 provides additional evidence of a rising trend in educational homogamy. Compared to the trends described above, all intermarriages crossing any educational barriers showed a similar decline since the early 1980s. In particular, the percentage of intermarriages crossing one educational category, which accounted for $90 \%$ of the heterogamous marriages, declined from $40 \%$ to $30 \%$. In addition, very few people with postsecondary education crossed three educational barriers and married an illiterate person.

Panel $\mathrm{B}$ and $\mathrm{C}$ of Figure 4 reveal rural-urban differences in the timing and degree of intermarriage decreases. The decline in the percentage of heterogamy in urban areas started in the early 1970s - around a decade earlier than in rural areas. Further, the decline in the percentage intermarriages was larger in urban areas than rural areas. In urban areas, the predominant type of intermarriages starting in the early 1970s was marriages between elementary and junior high school graduates; these marriages experienced the largest drop, declining from $48 \%$ to $8 \%$. In contrast, in rural areas, the largest percentage drop, from $40 \%$ to $8 \%$, took place among marriages formed between illiterate respondents and elementary school graduates. In short, the decline in the rate of heterogamy occurred earlier and was greater in urban areas than in rural areas. Overall, the rural-urban division in the decline of intermarriages is consistent with the different patterns of educational homogamy between rural and urban areas.

In summary, these descriptive results show that between 1970 and 2001 women in China have increasingly married spouses with similar educational attainment. The increases in the percentage of homogamous marriages took place earlier in urban areas 
than rural areas. However, the average educational attainment of both men and women increased in this time period, therefore the patterns described above may be partially due to changes in the educational levels of potential partners in the marriage pool (Mare 1991). Therefore, I use log-linear models to estimate the trends in educational homogamy in China from 1970 to 2000; these models reduce the distortion introduced by changes in the marginal distribution.

\subsection{Selection of models}

Table 3 reports the deviance $\mathrm{G}^{2}(-2 * \log$-likelihood) and Bayesian Information Criteria (BIC) statistics for log-linear models of the trends in assortative marriage rates between 1970 and 2000 for national, rural and urban samples. Models with the smallest $\mathrm{G}^{2}$ and most negative BIC fit the pooled data most closely. Because the model fit statistics for the rural and urban samples resemble those for the national sample, I present the model selection process for the national sample.

Model 1 is a saturated baseline model which assumes that the marginal distribution of couples' educational attainment and the association of couples' education vary by data source. The $\mathrm{G}^{2}$ and BIC indicate that this model does not fit the data well. Model 2 includes the homogamy parameters, assuming the homogamous association of couples' education varies by marriage cohort. This homogamy model increases the fit of the model, as shown by reductions in $\mathrm{G}^{2}$ and BIC. Since the BIC for Model 2 is still positive, in Model 3 I add diagonal parameters to the baseline model, relaxing the assumption of a single association for all four education categories. This change improves the model fit by a reduction of 2,176 points in $\mathrm{G}^{2}$ and results in a negative BIC (-427), at the expense of 20 degrees of freedom. However, Model 2 (including homogamy parameters) provides a better summary measure of the trends in educational homogamy in the United States (Schwartz and Mare 2005). Therefore, I use results from Model 2 to generate the general trends in educational homogamy, although the model does not fit as well as Model 3. 


\section{Figure 3: Changes in the percentage of educational assortative marriages for} women age 15-49: China, 1970-2001

Panel A. Percentage of homogamous and heterogamous marriages at the national level

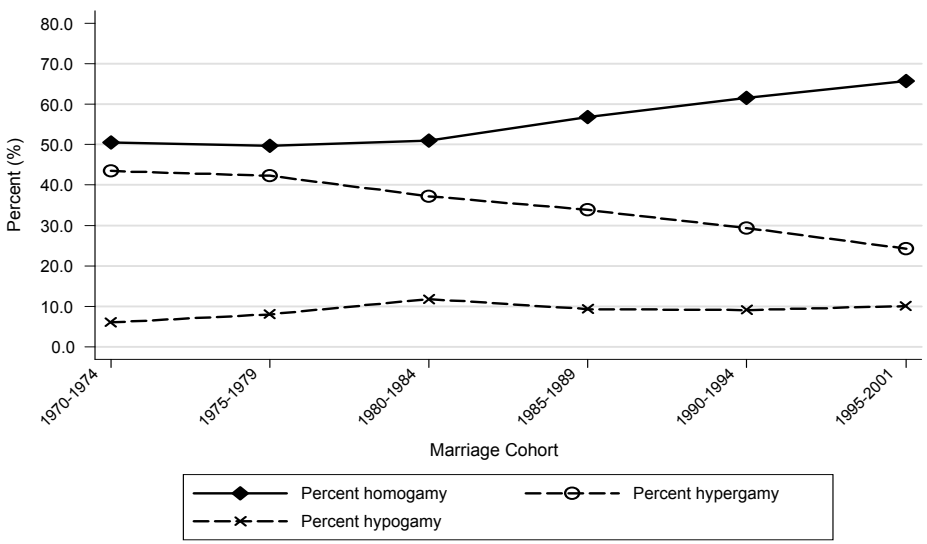

Source: 2000 China Population Census and 2001 Demographic Reproductive Health Survey.

Panel B. Percentage of homogamous marriages at the rural and urban sample

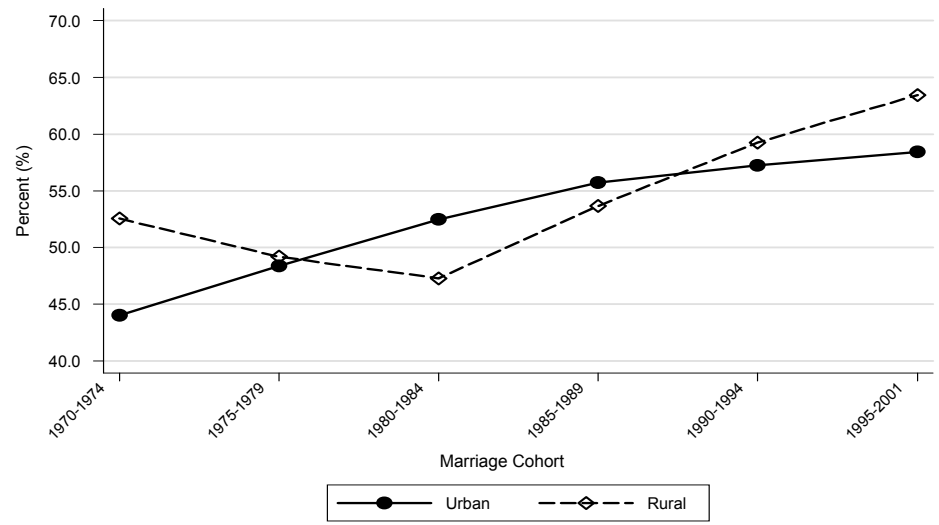

Source: 2000 China Population Census and 2001 Demographic Reproductive Health Survey. 
Han: Trends in educational assortative marriage in China from 1970 to 2000

\section{Figure 4: Percentage of heterogamous marriages crossing educational levels for women age 15-49: China, 1970-2001}

$\underline{\text { Panel A. National sample }}$

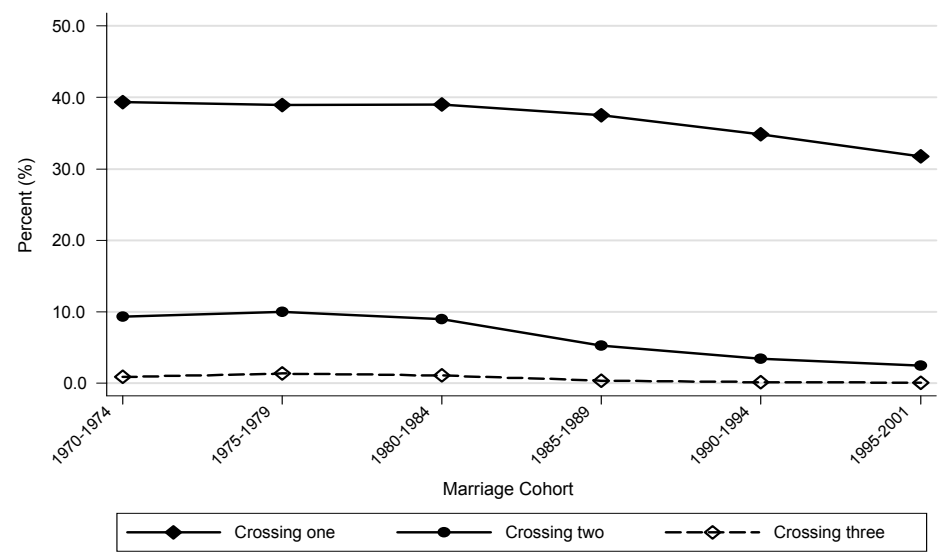

Source: 2000 China Population Census and 2001 Demographic Reproductive Health Survey.

$\underline{\text { Panel B. Urban sample }}$

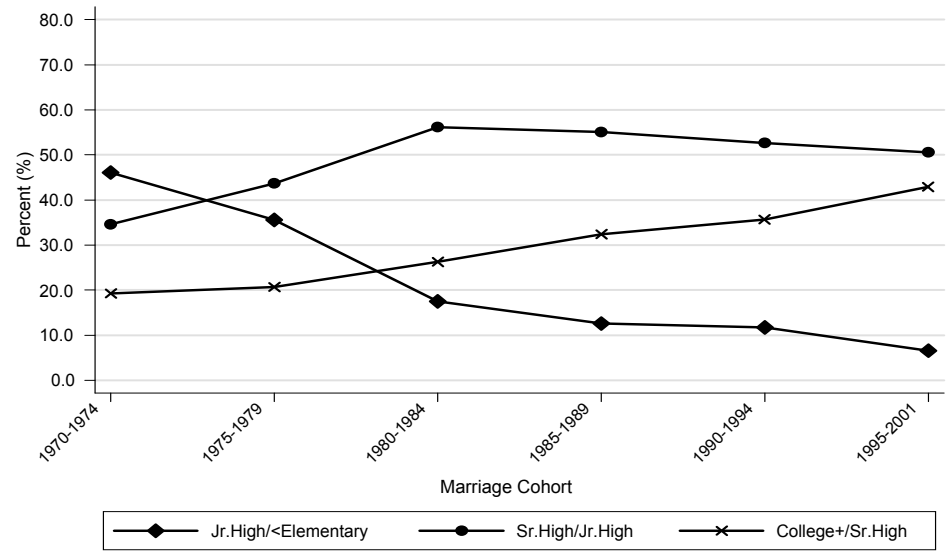

Source: 2000 China Population Census and 2001 Demographic Reproductive Health Survey. 


\section{Figure 4: (Continued)}

\section{$\underline{\text { Panel C. Rural sample }}$}

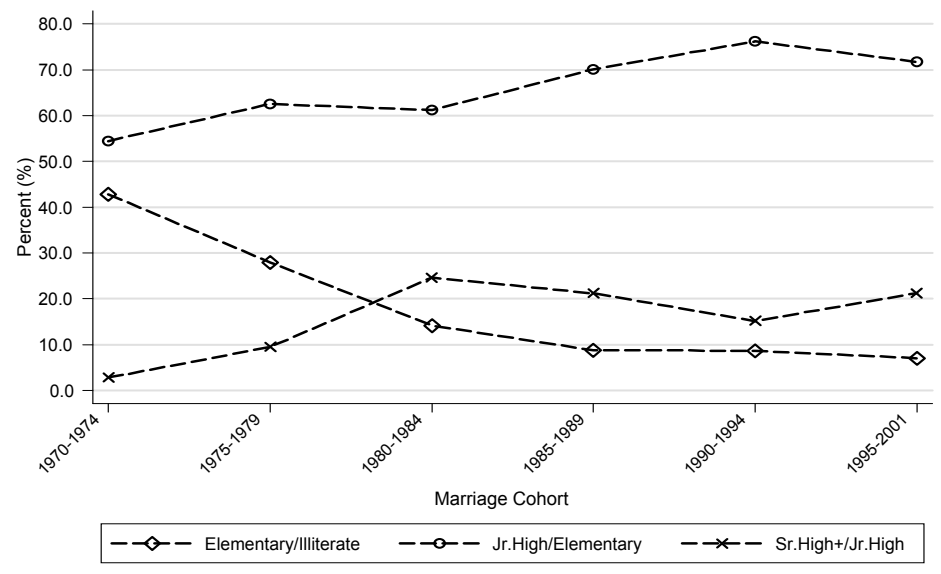

In order to test the hypothesized time-varying patterns in the permeability of educational barriers, I add crossing parameters for three educational barriers to the baseline model in Model 4, allowing the crossing parameters to be cohort-specific. The crossing model (Model 4) fits the data better than Model 3, with a significant reduction in $G^{2}\left(G^{2}[3]-G^{2}[4]=23\right.$. d.f.=-5) and BIC (BIC[3]-BIC[4] =85). Therefore, the timevarying crossing models capture variations in patterns of educational assortative mating well. In addition, Models 5-7 test the hypothesis that the association and crossing parameters vary by data source. Judging by the criteria of $\mathrm{G}^{2}$ and $\mathrm{BIC}$, these models fail to generate a better fit than Models 2-4. These results suggest that the estimated association and crossing parameters do not vary by data source. Therefore, I present the remaining results using pooled data. ${ }^{14}$

\footnotetext{
${ }^{14}$ Estimates for the first cohort are obtained using a modified model. The odds of homogamy and crossings for this cohort are estimated by holding source constant at the census level.
} 
Han: Trends in educational assortative marriage in China from 1970 to 2000

Table 3: Log-linear models of educational assortative marriages $(\mathrm{N}=\mathbf{2 3 5 , 0 7 5 )}$

\begin{tabular}{|c|c|c|c|c|c|c|c|c|c|}
\hline \multirow[b]{2}{*}{ Model } & \multirow[b]{2}{*}{ Description } & \multirow[b]{2}{*}{ Specifications } & \multicolumn{3}{|c|}{ National } & \multicolumn{2}{|c|}{ Rural } & \multicolumn{2}{|c|}{ Urban } \\
\hline & & & d.f. & $\mathbf{G}^{2}$ & BIC & $\mathbf{G}^{2}$ & BIC & $\mathbf{G}^{2}$ & $\mathrm{BIC}$ \\
\hline 1 & Baseline & $H C D W C D H W C$ & 90 & 2618 & 1500 & 672 & -414 & 503 & -487 \\
\hline 2 & Homogamy & Baseline $+O^{*} C$ & 85 & 1703 & 647 & 529 & -497 & 389 & -545 \\
\hline 3 & Diagonal & Baseline $+A^{*} C$ & 70 & 442 & -427 & 291 & -553 & 265 & -504 \\
\hline 4 & Crossings & Baseline $+X{ }^{*} C$ & 75 & 419 & -512 & 239 & -667 & 176 & -648 \\
\hline 5 & Homogamy*Source & Baseline $+O^{*} C^{*} D$ & 80 & 1694 & 700 & 506 & -459 & 386 & -493 \\
\hline 6 & Diagonal*Source & Baseline $+A^{*} C^{*} D$ & 50 & 399 & -222 & 249 & -354 & 249 & -311 \\
\hline 7 & Crossings *Source & Baseline $+X{ }^{*} C^{*} D$ & 60 & 392 & -353 & 188 & -536 & 159 & -500 \\
\hline 8 & Crossings, Homogamy & Baseline $+X^{\star} C O^{*} C$ & 70 & 118 & -751 & 109 & -744 & 60 & -710 \\
\hline 9 & Crossings, Diagonal & Baseline $+X^{\star} C A^{*} C$ & 65 & 103 & -704 & 90 & -694 & 57 & -657 \\
\hline 10 & $\begin{array}{l}\text { Crossings, Homogamy, } \\
\text { Hypergamy }\end{array}$ & Baseline $+X^{\star} C O^{*} C P^{*} C$ & 65 & 99 & -708 & 95 & -689 & 55 & -660 \\
\hline 11 & Crossings, Diagonal, Hypergamy & Baseline $+X^{\star} C A^{*} C P^{\star} C$ & 60 & 80 & -665 & 85 & -639 & 53 & -607 \\
\hline
\end{tabular}

Note: $H=$ Husband's education (1-4), $W=$ Wife's education (1-4), $C=$ Cohort (1-6), $D=$ Data source $(0,1), O=H o m o g a m y ~(0,1)$, $A=$ Diagonal (1-4), $X=$ Crossing parameters (1-3), $P=$ Hypergamy $(0,1)$.

Models 8-11 relax the assumption that the homogamy, diagonal and hypergamy parameters are all time invariant in the crossing model. All of these models fit better than Model 4 with restrictions. Model 8 (crossing with homogamy) fits the data most closely, as indicated by the most negative BIC (BIC[4]-BIC[8] $=239$, d.f.=5). These results suggest that: (1) patterns of educational assortative marriage changed among the six marriage cohorts and (2) temporal variations were captured by changes in crossing parameters and homogamy parameters.

\subsection{Results of Log-linear models}

\subsubsection{Estimated trends in educational homogamy at the national level}

Figure 5 includes the predicted odds of homogamy relative to heterogamy from 1970 to 2001 for women age 15 to 49 in China. The increasing odds of homogamy across cohorts confirm my first hypothesis and show a pattern similar to the one depicted in the descriptive analysis and presented in Figure 3. Comparing the first two marriage cohorts (1970-1974 and 1975-1979) to the third cohort (1980-1984), the odds of homogamy declined from 7.0 to 6.0 , indicating that Chinese women were less likely to marry a spouse with the same level of education in the early 1980s than they were in the early 1970s. This decrease in educational homogamy between the 1970s and the early 
1980s is consistent with previous results reported by Raymo and Xie (2000) and Smits, Ultee and Lammers (2000).

In contrast, the rising homogamous marriage rates after the mid-1980s are a new phenomenon. The odds of homogamy shifted direction following the early 1980s. Indeed, a dramatic increase in the odds of educational homogamy took place between 1980 and 1994. The odds of homogamy climbed from 6.0 for the 1980-1984 cohort to 9.0 for the 1995-2001 marriage cohort. These results suggest that the association between spouses' educational attainment has strengthened between 1980 and 2001. Overall, the estimated increasing national-level rate of educational homogamy between the 1980s and 1990s is consistent with studies based on the 1990 China Census and other Surveys (Esteve and McCaa 2008; Song 2009), despite different degrees of homogamy.

To further validate the trends found above, I calculated the odds ratios of marrying a partner with a similar education level, relative to crossing into the adjacent category and entering a heterogamous marriage for members of all marriage cohorts in national, urban and rural samples, using the methods illustrated in Smits and Park (2009). In Appendix 2 I reported the odds ratios based upon the $2 * 2$ contingency table. At the national level, the odds of forming educationally homogamous marriages relative to intermarriages increased across the six marriage cohorts for any educational strata despite declines or fluctuations before 1980. The trends for the odds ratios in rural and urban areas essentially resembled the increasing homogamy trends estimated from the log-linear model in Figure 5. In short, both the log-linear modeling approach and the $2 * 2$ contingency table method reveal rising educational homogamy between 1980 and 2000 in China. ${ }^{15}$

\subsubsection{The rural-urban division in educational homogamy}

Although the results for the rural sample resemble the national-level decline and increase in educational homogamy, the urban sample shows a distinct pattern with regard to both the degree and the timing of changes. Compared to the same cohort in the rural sample, the estimated odds of educational homogamy were 1.7 points lower for the 1970-1974 marriage cohort of the urban sample. Yet, the rural-urban

\footnotetext{
${ }^{15}$ Smits and Park (2009), using odds ratios from 2*2 contingency tables from 1970 to 1990 in China at the national level, reported a decline in educational homogamy. One possible explanation for the discrepancy between this study and Park and Smits (2009) was the use of different definitions of marriage and different data sources. For this study I use information about the first marriage in the 2000 Census, which was not available in the 1990 Census data used by Smits and Park (2009).
} 
discrepancy in the odds of educational homogamy began to diminish among the 19952001 cohorts. There were also rural-urban differences in timing; the estimated odds of educational homogamy started to increase approximately ten years earlier in the urban sample than in the rural sample. The resemblance in education among urban couples began to increase in the late 1970s, while rural couples were increasingly more likely to marry within their own educational categories only after the mid-1980s.

The current results indicating increasing educational homogamy in urban areas after the 1970s are consistent with results reported in a study of 20 cities in China (Song 2009). Using data from "The State and Life Chances in China from 1949-94," Song (2009) found the rate of educational homogamy was higher among the 1977-1994 marriage cohorts than among the 1966-1976 cohorts. Using refined measures of marriage cohorts, this study not only identifies the timing and patterns of increasing homogamy between 1970 and 1990, but also reveals slower growth in the late 1990s in urban areas. Further, this study is the first to show increasing spousal resemblance in rural areas after the early 1980s. In short, the current results - showing rising levels of educational homogamy in both urban and rural areas-support the first hypothesis, which states that educational expansion, the increasing economic value of education, and the increasingly common practice of delaying marriage have all led to important changes in marriage patterns. Greater degrees of spousal resemblance in China in the late 1990s also indicate higher levels of social closure across educational strata.

It is worthwhile to note that the level of the educational homogamy found here is relatively high compared to rates in the United States and those found in other studies of China (Smits, Ultee and Lammers 1998, 2000; Raymo and Xie 2000; Xu, Ji and Tung 2000; Schwartz and Mare 2005; Esteve and McCaa 2008; Song 2009). Between 1940 and 2003 the odds of educational homogamy fluctuated between 3 and 4 in the U.S. (Schwartz and Mare 2005). The higher level of educational homogamy in China may reflect both the high value placed on social-status-based matching in mate selection and greater institutional controls in marriage selection (Smits, Ultee and Lammers 1998; Song 2009). The difference between the degree of educational homogamy in China found in this study and other research most likely results from differences in data sources, age ranges of samples, definitions of marriage cohorts and model specifications. For example, Esteve and McCaa (2008) restricted their sample to women age 15 to 34 years in prevailing marriages in the 1980 and 1990 China Census, while in the current study I selected women age 15 to 49 in their first marriage in the 2000 Census. 
Figure 5: Estimated odds of educational homogamy relative to heterogamy for women age 15-49: China, 1970-2001

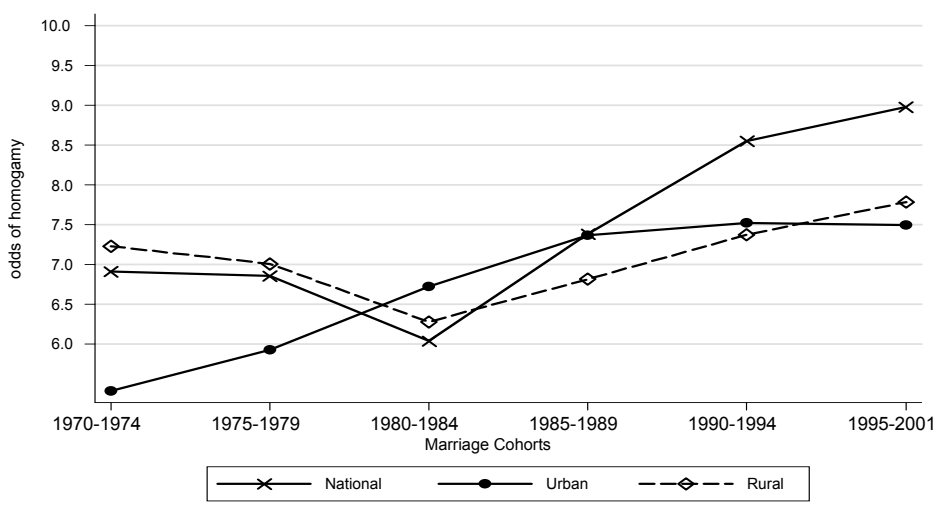

Source: 2000 China Population Census and 2001 Demographic Reproductive Health Survey

\subsubsection{Estimated trends in educational heterogamy}

The crossing odds represent couples' hesitation to enter into intermarriages. I summarize the odds of crossing any educational barriers for respondents with all levels of education in Table 4. The crossing models show that the odds of intermarriage declined across all levels of the educational distribution after the early 1980s, which confirms the increasing educational homogamy rate estimated above. The parallel declines of the crossing odds indicate that, compared to those who married in the 1970s, couples who married in the 1990s were less likely to cross educational barriers and more likely to marry within their educational categories. Because more than $80 \%$ of intermarriages crossed one educational barrier, I present the parameter estimates for crossing one educational barrier for women age 15 to 49 in China in Figure 6.

The national patterns for all types of intermarriages that cross one educational barrier show a parallel drop between 1985 and 2001 in Panel A of Figure 6. The first noticeable pattern is that the rate of entering into intermarriages is similar among respondents who are poorly educated and those who are highly educated. For example, for high school or college graduates, the odds of marrying a partner with less education, rather than marrying one with a similar education level, were 0.34 among the 19701974 cohorts, and the odd for elementary school graduates were 0.37 . For both groups, the odds of intermarriage dropped to 0.2 among the 1995-2001 cohorts. Another notable finding is that the timing and the degree of drops in the odds of intermarriages are 
roughly similar across the entire educational distribution. For each group, the odds of intermarriages were cut in half between 1985 and 1995. For high school or college graduates, the odds of marrying a junior high school graduate declined from 0.5 to 0.2 . In short, couples married between 1980 and 1994 experienced the most remarkable reduction in the probability of marrying a partner with less education. As more than two-thirds of respondents graduated from high school in the late 1990s, these declining rates of intermarriage indicate that the once permeable barriers became rigid. Finally, the results reveal that high school graduates, who had the highest odds of heterogamy in both rural and urban samples, experienced a larger drop in the odds of intermarriage than those located either at the top or at the bottom of the educational distribution between the early 1980s and late 1990s. Overall, this trend of declining odds of educational heterogamy is in line with the increasing odds of homogamy. In short, the fact that the largest drop in the odds of marrying a partner with less education occurs for high school graduates confirms my second hypothesis. These findings suggest that the permeability of barriers to secondary education in the marriage market was also lowered in the 1990s.

Panels B and C of Figure 6 show that urban couples differed significantly from rural couples in the odds of marrying a partner with less education. Differences lay in the magnitude and timing of the decline, despite parallel drops in the crossing odds. First, the rate of marrying a partner with less education was lower in urban areas than in rural areas across the entire educational distribution, indicating a more rigid urban marriage market. In particular, the barriers to marrying highly educated respondents were less permeable in urban areas than in rural areas. For example, among the 19701974 cohort, a senior high school graduate in an urban area was 0.6 times less likely to marry a junior high school graduate than to marry a classmate; however, in rural areas high school graduates in the 1970-1974 cohort were 0.4 times less likely to marry a junior high graduate. This ratio declined to from 1.5 to 1 for the 1995-2001 cohort. In addition, the odds of marrying a partner with less education among college graduates in urban areas remained below 0.1 between 1970 and 2001, suggesting that college education may be the most difficult barrier to cross.

Further, the decline in the odds of marrying a partner with less education took place about five years earlier in urban areas, as compared to rural areas. Urban couples marrying between 1980 and 1984 were less likely to marry a partner with less education than were compared to couples marrying between 1975 and 1979. In contrast, the odds of entering an intermarriage among rural couples started to drop between the marriage cohorts of 1980-1984 and 1985-1989. In addition, the declining odds of marrying a partner with less education seemed to stall in urban areas in the 1990s, while the decreasing trend persisted in rural areas. In short, the earlier drops in urban areas hold true for intermarriages crossing one educational barrier. 
Figure 6: Estimated odds of crossing one educational barrier, relative to homogamy for women age 15-49: China, 1970-2001

Panel A: National Sample

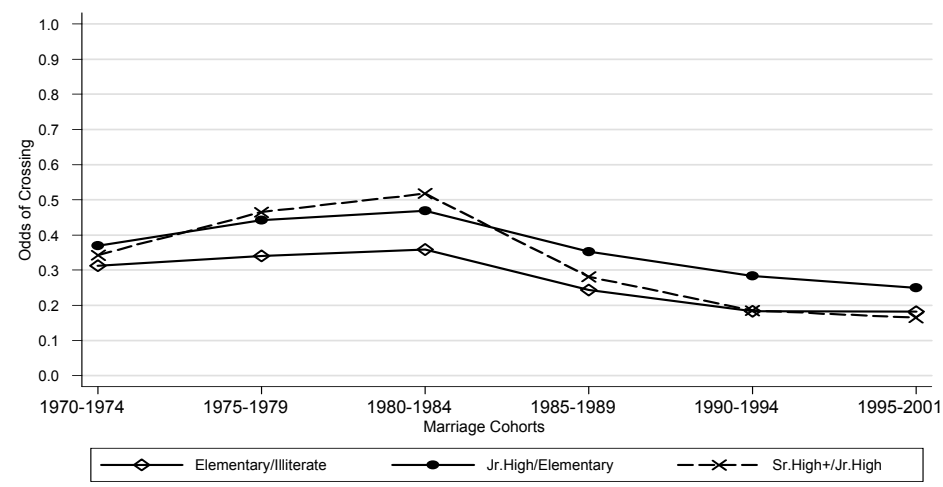

Source: 2000 China Population Census and 2001 Demographic Reproductive Health Survey

\section{$\underline{\text { Panel B: Urban Sample }}$}

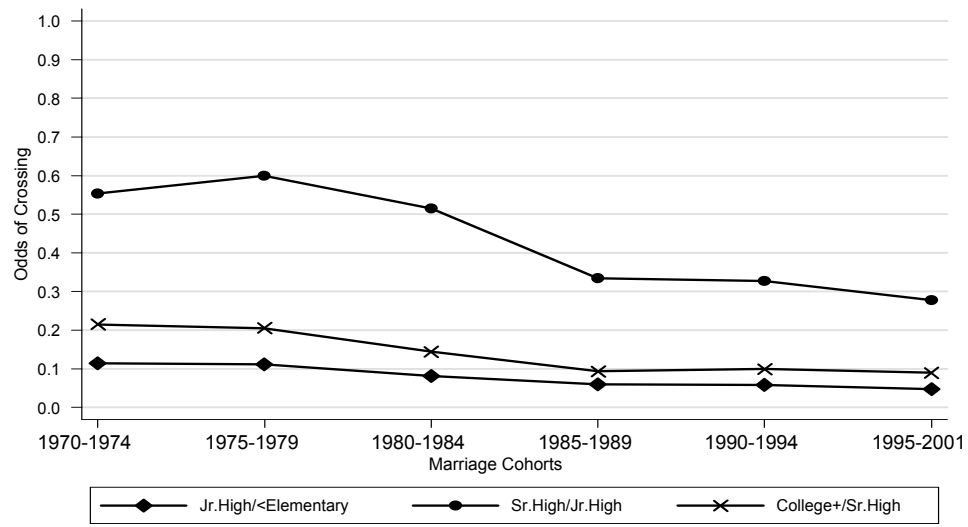

Source: 2000 China Population Census and 2001 Demographic Reproductive Health Survey. 


\section{Figure 6: (Continued)}

\section{Panel C: Rural Sample}

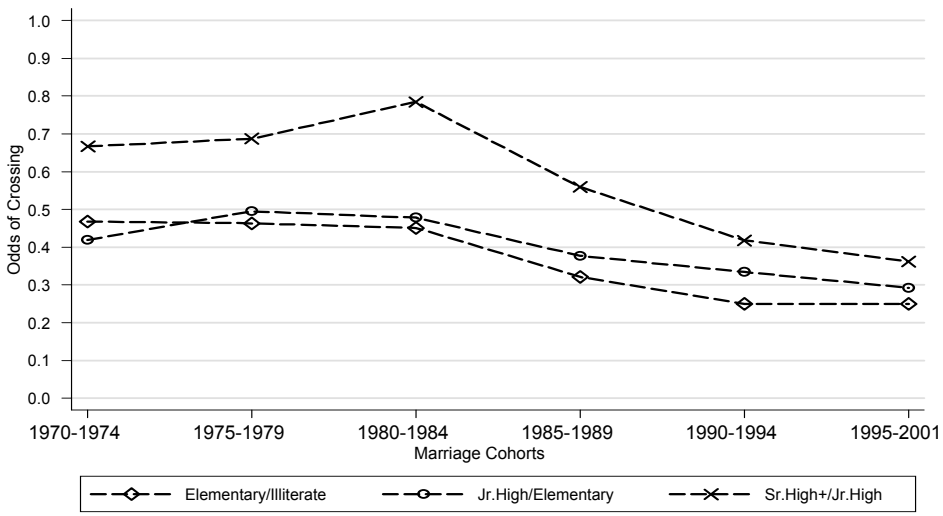

Source: 2000 China Population Census and 2001 Demographic Reproductive Health Survey.

Considering the fact that the overall odds of educational homogamy increased after the early 1980s, the decline in odds of intermarriages crossing one educational barrier further indicate that people with high school or college education may increasingly marry within their own educational category, and there are fewer chances for people with low education to marry a partner with a higher level of education. Since intermarriages crossing one educational barrier account for nearly $80 \%$ of the total intermarriages and two-thirds of respondents had secondary and postsecondary education, the greatest drop in the odds of intermarriages among these high school graduates between 1985 and 1994 may leave a large number of poorly educated people behind in the marriage market.

Finally, the odds of intermarriage across two or more educational barriers show a similar decrease across educational strata. Table 4 presents the odds of marrying a partner with less education across each level of the educational distribution. For almost every group, the odds of crossing two or three educational barriers were cut in half between 1980 and 2000. For college graduates in urban areas, the odds of marrying junior high school graduates (i.e. crossing two educational barriers) shrank from 0.11 to 0.02 , and the chances of marrying respondents with less than six years of schooling (i.e. crossing three educational barriers) in the late 1990s were only one tenth of the odds in the late 1970s. Results showing the weakest odds of intermarriages among college graduates and those with lower education suggest a greater degree of social closure 
among college graduates than among other educational groups. These findings also indicate that it is increasingly difficult for the poorly educated to move up the social strata through marriage.

In summary, my investigation of educational homogamy and intermarriage yields consistent findings that the odds of educational homogamy increased between 1980 and 2000; however, the odds of intermarriage across educational barriers varied across the educational distribution and by rural/urban status. The generally decreasing odds of crossing any educational barriers for all educational categories provide strong evidence that the social distance between groups has strengthened between 1984 and 2001 in China.

Table 4: $\quad$ Estimated odds of crossing educational barriers for women age 15-49: China, 1970-2001

\begin{tabular}{|c|c|c|c|c|c|c|c|}
\hline \multirow{3}{*}{$\begin{array}{c}\text { Rural } \\
\begin{array}{l}\text { Husband's } \\
\text { education }\end{array}\end{array}$} & \multicolumn{7}{|c|}{ Urban } \\
\hline & \multicolumn{3}{|c|}{ Wife's education } & \multirow[t]{2}{*}{$\begin{array}{l}\text { Husband's } \\
\text { education }\end{array}$} & \multicolumn{3}{|c|}{ Wife's education } \\
\hline & Illiterate & Elementary & $\begin{array}{c}\text { Junior high } \\
\text { school }\end{array}$ & & $\begin{array}{c}<< \\
\text { Elementary }\end{array}$ & $\begin{array}{c}\text { Junior high } \\
\text { school }\end{array}$ & $\begin{array}{c}\text { Senior high } \\
\text { school }\end{array}$ \\
\hline 1970-1974 & & & & 1970-1974 & & & \\
\hline Elementary & 0.468 & & & Junior high school & 0.114 & & \\
\hline Junior high school & 0.196 & 0.419 & & Senior high school & 0.063 & 0.554 & \\
\hline Senior high school+ & 0.131 & 0.279 & 0.667 & College and up & 0.014 & 0.119 & 0.215 \\
\hline $1975-1979$ & & & & $1975-1979$ & & & \\
\hline Elementary & 0.463 & & & Junior high school & 0.111 & & \\
\hline Junior high school & 0.229 & 0.495 & & Senior high school & 0.067 & 0.599 & \\
\hline Senior high school+ & 0.158 & 0.340 & 0.687 & College and up & 0.014 & 0.123 & 0.205 \\
\hline 1980-1984 & & & & $1980-1984$ & & & \\
\hline Elementary & 0.451 & & & Junior high school & 0.081 & & \\
\hline Junior high school & 0.215 & 0.478 & & Senior high school & 0.042 & 0.515 & \\
\hline Senior high school+ & 0.169 & 0.375 & 0.785 & College and up & 0.006 & 0.074 & 0.144 \\
\hline 1985-1989 & & & & 1985-1989 & & & \\
\hline Elementary & 0.321 & & & Junior high school & 0.060 & & \\
\hline Junior high school & 0.121 & 0.377 & & Senior high school & 0.020 & 0.334 & \\
\hline Senior high school+ & 0.068 & 0.211 & 0.559 & College and up & 0.002 & 0.031 & 0.093 \\
\hline 1990-1994 & & & & 1990-1994 & & & \\
\hline Elementary & 0.250 & & & Junior high school & 0.058 & & \\
\hline Junior high school & 0.083 & 0.334 & & Senior high school & 0.019 & 0.327 & \\
\hline Senior high school+ & 0.035 & 0.140 & 0.418 & College and up & 0.002 & 0.032 & 0.099 \\
\hline $1995-2001$ & & & & $1995-2001$ & & & \\
\hline Elementary & 0.249 & & & Junior high school & 0.047 & & \\
\hline Junior high school & 0.073 & 0.292 & & Senior high school & 0.013 & 0.277 & \\
\hline Senior high school+ & 0.026 & 0.106 & 0.362 & College and up & 0.001 & 0.025 & 0.090 \\
\hline
\end{tabular}

Source: 2000 China Population Census and 2001 Demographic Reproductive Health Survey, N=235,075. 


\subsection{Explanations of rising educational homogamy trends}

One possible explanation of rising rates of educational homogamy in China after the 1980s is that economic returns on education increased between 1970 and 2000. Increasing homogamy at the national level coincided with the increasing economic value placed on education during the market transition. Wider income inequalities across educational strata in urban areas echoed greater degrees of social closure in the marriage market.

At the national level, returns on schooling increased rapidly between the late 1970s and the late 1980s, and then accelerated even more in the 1990s (Fleisher, Sabirianova and Wang 2005). The high yields of education may have increased people's motivation to find highly educated partners. Most importantly, the education premium became larger for high school and college graduates. Moderate estimates showed that the economic returns on college education, relative to high school, rose from $4.9 \%$ in 1988 to $15.0 \%$ in 1995 (Knight and Song 2003). In addition to direct economic rewards, a college degree was crucial to provide access to prestigious occupations and promotional opportunities (Zhao and Zhou 2007). In short, highly educated Chinese individuals may be eager to maintain and increase their social status by marrying an equally educated person, resulting in higher levels of educational homogamy.

The distinct patterns of educational homogamy for rural and urban areas echoed the lasting rural-urban division in education rewards in contemporary China. First, the economic returns on education were higher in urban areas than in rural areas due to a unique occupational structure and reward system. After the 1979 reform, the burgeoning private sector rewarded the highly educated in urban areas (Li 2003) and one additional year of schooling was, on average, associated with a $10.2 \%$ increase in wages in 2000 (Zhang et al. 2005). Schooling, however, did not enhance the productivity of farm workers and therefore did not yield direct economic value in rural China (Zhao 1999). Studies showed that the economic returns on schooling in farming areas only rose to a positive return of about 3\% for household farming in 1990 (Li and Zhang 1998). In addition, the average return on a year of education was $4.3 \%$ among rural local wage earners, whereas it was $7.8 \%$ among all migrants in 2000 (De Brauw and Rozelle 2008). In short, given that urban areas produce higher economic returns on education, the highly educated in these areas are more likely to marry homogamously than to marry a partner with less education.

Second, the increases in economic returns on education began earlier in urban areas than in rural areas. The substantial increase in economic returns in urban areas occurred in the early 1980s, due to reward system reform in the state-owned sector and the mushrooming of the private sector after 1979. Rural areas, however, did not experience sweeping changes until the late 1980s, when employment in township- 
owned enterprises and migration offered opportunities to earn income and increased incentives to invest in education (Yang 1997; Zhao 1999). Thus, the later increases in schooling returns in rural areas may be associated with later increases in educational homogamy.

Third, income inequality across educational strata became wider in urban areas than in rural areas. In urban areas, the income gaps between college graduates and those with elementary school education or illiterates nearly doubled after 1979 (Zhou 2002). In contrast, in the rural sector, economic returns on secondary education, relative to elementary education were $11.2 \%$ in 1991 , and the income gap between elementary school graduates and illiterate respondents was even smaller (Wei, et al. 1999). Thus, given the greater rewards experienced by highly educated individuals and the presence of wider income gaps across the educational strata in urban areas, the chances of entering intermarriages across educational barriers are slimmer in these areas, compared to rural areas, and thus the barriers to marrying a partner with more education experienced by the poorly educated are more difficult to overcome.

In summary, increasing economic returns on senior high school and college education may be associated with a greater degree of educational homogamy in China from 1970 to 2000 . As higher levels of education promised economic prosperity and security, and the income gaps between the highly educated and the poorly educated became wider, the highly educated had more incentive to maintain or increase their social status by marrying within their own educational category. As the income gaps across the educational strata were larger in urban areas than in rural areas, the estimated trends in intermarriage revealed a lower degree of heterogamous marriages and less permeable educational barriers in the urban marriage market.

\section{Summary and conclusion}

Using data from the 2000 China Population Census and the 2001 Demographic Reproductive Health Survey, I examine the trends in educational assortative marriage from 1970 to 2001, a period of remarkable economic growth in China. I demonstrate that respondents increasingly married those with a similar level of educational. For instance, the estimated odds of educational homogamy were 6 in the early 1970s and rose to 9 in the late 1990s. However, these increases were not monotonic. Between the early 1970s and the 1980s, the odds of educational homogamy decreased slightly, which was consistent with previous findings (Raymo and Xie 2000; Smits, Ultee and Lammers 2000). In addition, the growth in the odds of educational homogamy slowed in the late 1990s, partly due to a smaller decline in the odds of forming intermarriages crossing one or two educational barriers. This study goes beyond previous studies by 
identifying increasing homogamy in China after the early 1980s. Furthermore, this study finds that increasing spousal resemblance occurred a decade earlier and at a higher level in urban areas compared to rural areas. Urban areas showed consistently increasing rates while rural area rates declined before the 1980s. In short, this study is the first to report the distinct rural-urban division of educational homogamy in China during the period from 1970 to 2000.

In order to determine how patterns of intermarriage varied across the educational distribution, I used crossing models to estimate differences in the odds of crossing barriers for people with different levels of education. Results showed that more intermarriages took place between people with middle levels of education than people both at the top and bottom. In addition, a greater drop in the odds of intermarriage occurred among people with middle levels of education, which indicates that people at the bottom of the educational strata increasingly have fewer chances to marry a partner with a higher level of education. Second, consistent decreases in the odds of crossing any barrier for college and senior high school graduates suggest growing social closure among the highly educated because they are less likely to marry outside their own educational group.

In short, I demonstrate that the national-level educational homogamy rates increased substantially between 1980 and 2000, as China experienced booming economic growth and a market transition. The findings are consistent with the status attainment hypothesis. During the unprecedented process of social change, the burgeoning number of homogamous marriages among highly educated individuals suggests that people greatly value education in spousal selection. The increasing educational homogamy rates parallel rising economic returns on education, since China experienced a sweeping market transition. As the earning gap between highly educated individuals and poorly educated individuals widened, highly educated individuals increasingly married within their own group to maintain their social status. These respondents were less likely to cross any educational barriers and more likely to avoid downward mobility. As a result, poorly educated people have much lower chances of achieving higher social status through marriage. The much wider earning gaps across the educational strata in urban areas provide plausible explanations for the greater degrees of social closure in urban areas.

The decreasing odds of educational heterogamous marriage in China not only indicate greater social distance between social groups, but also have important implications for increasing earning inequality across households and the social reproduction of inequality among future generations. Studies in European countries have shown that assortative mating explains $10-30 \%$ of earning gaps between households (Fernandez, Guner and Knowles 2005; Ermisch, Francesconi and Siedler 2006). As the market transition theory suggests, when returns on education and political 
capital increase, households formed by people with lower educational levels may be more disadvantaged, because they lack access to both education and political capital. As a result, the concentration of marriages within lower education categories may generate continuous inequalities in this generation as well as in future generations in China.

Future studies are needed in three areas. First, studies employing a life course approach and longitudinal studies of individual marital choices will help researchers identify key factors influencing marriage patterns (Blossfeld 2009). Second, a two-sided choice model should be employed to analyze the actual mate selection process which includes preferences and potential partners of both husbands and wives. This method will allow a more nuanced understanding of the critical role of education in the marriage market. Third, a study of marriage patterns among migrant workers is necessary as the rural-to-urban migration movement in the 1990s brought substantial changes to the cultural and economic value of education in rural China.

\section{Acknowledgements}

I am grateful to Christine Schwartz, Jim Raymo and Alberto Palloni for helpful comments to earlier drafts. The editor and reviewers at Demographic Research provided constructive comments and advice. 


\section{References}

Bian, Y. and Logan, J.R. (1996). Market transition and the persistence of power: The changing stratification system in urban China. American Sociological Review 61(5): 739-578. doi:10.2307/2096451.

Bian, Y. (2002). Chinese social stratification and social mobility. Annual Review of Sociology 28: 91-116. doi:10.1146/annurev.soc.28.110601.140823.

Blossfeld, H. (2009). Educational assortative marriage in comparative perspective. Annual Review of Sociology 35(1): 513-530. doi:10.1146/annurev-soc-070308115913.

De Brauw, A. and Rozelle, S. (2008). Reconciling the returns to education in off-farm wage employment in rural China. Review of Development Economics 12(1): 5771. doi:10.1111/j.1467-9361.2007.00376.x.

Deng, Z. and Treiman, D.J. (1997). The impact of the cultural revolution on trends in educational attainment in the People's Republic of China. The American Journal of Sociology 103(2): 391-428. doi:10.1086/231212.

Diamant, N.J. (2000). Re-examining the impact of the 1950 marriage law: State improvisation, local initiative and rural family change. The China Quarterly (161): 172-198. doi:10.1017/S0305741000003982.

Ermisch, J., Francesconi, M., and Siedler, T. (2006). Intergenerational mobility and marital sorting. The Economic Journal 116(513): 659-679. doi:10.1111/j.14680297.2006.01105.x.

Esteve, A. and McCaa, R. (2008). Assortative mating patterns in the developing world. Paper presented at the 2009 IUSSP Seminar on Changing Transitions to Marriage, New Delhi, September 10-12, 2008.

Fan, C. and Huang, Y. (1998). Waves of rural brides: female marriage migration in China. Annals of the Association of American Geographers 88(2): 227-251. doi:10.1111/1467-8306.00092.

Fernandez, R., Guner, N., and Knowles, J. (2005). Love and money: A theoretical and empirical analysis of household sorting and inequality. The Quarterly Journal of Economics 120(1): 273-344. doi:10.1162/0033553053327498.

Fleisher, B.M., Sabirianova, K., and Wang, X. (2005). Returns to skills and the speed of reforms: Evidence from central and eastern Europe, China, and Russia. Journal of Comparative Economics 33(2): 351-370. doi:10.1016/j.jce.2005.03.003. 
Goodkind, D. and Branch, E. (2006). Marriage squeeze in China: historical legacies, surprising findings. Paper presented at the 2006 Annual Meeting of the Population Association of America, Los Angeles, March 30-April 1, 2006.

Hannum, E. (1999). Political change and the urban-rural gap in basic education in China, 1949-1990. Comparative Education Review 43(2): 193-211. doi:10.1086/447554.

Hannum, E., Wang, M. and Adams, J. (2008). Urban-rural disparities in access to primary and secondary education under market reform. In: Whyte, M.K. (ed.). One country, two societies? Rural-urban inequality in contemporary China. Cambridge: Harvard University Press.

Hauser, S.M. and Xie, Y. (2005). Temporal and regional variation in earnings inequality: Urban china in transition between 1988 and 1995. Social Science Research 34(1): 44-79. doi:10.1016/j.ssresearch.2003.12.002.

International Monetary Fund (2000). The World Economic Outlook (WEO) database [electronic resource]. Washington, D.C.: International Monetary Fund. http://www.imf.org/external/pubs/ft/weo.

Kalmijn, M. (1991). Status homogamy in the United States. The American Journal of Sociology 97(2): 496-523. doi:10.1086/229786.

Kalmijn, M. (1998). Intermarriage and homogamy: Causes, patterns, trends. Annual Review of Sociology 24: 395. doi:10.1146/annurev.soc.24.1.395.

Knight, J. and Song, L. (2003). Increasing wage inequality in China: Extent, elements and evaluation. Economics of Transition 4: 597-619. doi:10.1111/j.09670750.2003.00168.x.

Lewis, S.K. and Oppenheimer, V.K. (2000). Educational assortative mating across marriage markets: Non-hispanic whites in the United States. Demography 37(1): 29-40. doi:10.2307/2648094.

Li, B. and Walder, A.G. (2001). Career advancement as party patronage: Sponsored mobility into the Chinese administrative elite, 1949-1996. The American Journal of Sociology 106(5): 1371-1408. doi:10.1086/320816.

Li, H. (2003). Economic transition and returns to education in China. Economics of Educational Review 22(3): 317-328. doi:10.1016/S0272-7757(02)00056-0.

Li, T. and Zhang, J. (1998). Returns to education under collective and household farming in China. Journal of Development Economics 56(2): 307-335. doi:10.1016/S0304-3878(98)00068-6.

Mare, R.D. (1991). Five decades of educational assortative mating. American Sociological Review 56(1): 15-32. doi:10.2307/2095670. 
National Bureau of Statistics of China (2000). China Population Census. Beijing: National Bureau of Statistics of China.

Nee, V. and Matthews, R. (1996). Market transition and societal transformation in reforming state socialism. Annual Review of Sociology 22: 401-435. doi:10.1146/annurev.soc.22.1.401.

Nee, V. (1991). Social inequalities in reforming state socialism: Between redistribution and markets in china. American Sociological Review 56(3): 267-282. doi: $10.2307 / 2096103$.

Nee, V. (1989). A theory of market transition: From redistribution to markets in state socialism. American Sociological Review 54(5): 663-681. doi:10.2307/2117747.

Pochagina, O. (2004). Chinese youth: Attitude toward family and marriage. Far Eastern Affairs 32(1): 133-149.

Qian, Y. (2000). The process of China's market transition (1978-1998): The evolutionary, historical, and comparative perspectives. Journal of Institutional and Theoretical Economics 156(1): 151.

Qian, Z. and Preston, S.H. (1993). Changes in American marriage, 1972 to 1987: Availability and forces of attraction by age and education. American Sociological Review 58(4): 482-495. doi:10.2307/2096072.

Qian, Z. (1998). Changes in assortative mating: The impact of age and education, 19701990. Demography 35(3): 279-292. doi:10.2307/3004036.

Raymo, J.M. and Xie, Y. (2000). Temporal and regional variation in the strength of educational homogamy. American Sociological Review 65(5): 773-781. doi:10.2307/2657546.

Schwartz, C.R. and Mare, R.D. (2005). Trends in educational assortative marriage from 1940 to 2003. Demography 42(4): 621-646. doi:10.1353/dem.2005.0036.

Schwartz, C.R. and Mare, R.D. (2003). The effects of marriage, marital dissolution, and educational upgrading on educational assortative mating. [unpublished manuscript] Los Angeles: California Center of Population Research.

Shu, X. and Bian, Y. (2003). Market transition and gender gap in earnings in urban China. Social Forces 81(4): 1107-1145. doi:10.1353/sof.2003.0070.

Shu, X. (2004). Education and gender egalitarianism: The case of China. Sociology of Education 77(4): 311-336. doi:10.1177/003804070407700403.

Smits, J., Ultee, W., and Lammers, J. (1998). Educational homogamy in 65 countries: An explanation of differences in openness using country-level explanatory variables. American Sociological Review 63(2): 264-285. doi:10.2307/2657327. 
Smits, J., Ultee, W., and Lammers, J. (2000). Reply to Raymo and Xie: More or less educational homogamy? A test of different versions of modernization theory using cross-temporal evidence for 60 countries. American Sociological Review 65(5): 781-788. doi:10.2307/2657547.

Smits, J. (2003). Social closure among the higher educated: Trends in educational homogamy in 55 countries. Social Science Research 32(2): 251-277. doi:10.1016/S0049-089X(02)00049-2.

Smits, J. and Park, H. (2009). Five decades of educational assortative mating in ten East Asian societies. Social Forces 88(1): 227-255. doi:10.1353/sof.0.0241.

Song, L. (2009). The effect of the cultural revolution on educational homogamy in urban China. Social Forces 88(1): 257. doi:10.1353/sof.0.0246.

State Fertility Planning Commission of China (2001). Chinese Demographic Reproductive Health Survey. Beijing: State Fertility Planning Commission of China.

Walder, A.G. (1996). Markets and inequality in transitional economies: Toward testable theories. The American Journal of Sociology 101(4): 1060. doi:10.1086/230789.

Walder, A.G. (2002). Markets and income inequality in rural china: Political advantage in an expanding economy. American Sociological Review 67(2): 231-253. doi: $10.2307 / 3088894$.

Wang, F. (2005). Organizing through division and exclusion: China's hukou system. Stanford: Stanford University Press.

Wei, X., Tsang, M.C., Xu, W., and Chen, L. (1999). Education and earnings in rural China. Education Economics 7(2): 167-187. doi:10.1080/09645299900000014.

$\mathrm{Wu}, \mathrm{X}$. and Treiman, D.J. (2004). The household registration system and social stratification in China: 1955-1996. Demography 41(2): 363-384. doi:10.1353/dem.2004.0010.

Xia, Y. and Zhou, Z. (2003). The transition of courtship, mate selection and marriage in China. In: Hamon, R. and Ingoldsby, B. (eds.). Mate Selection Across Cultures. Thousand Oaks: Sage Publications, Inc. 231-246.

Xie, Y. and Hannum, E. (1996). Regional variation in earnings inequality in reform-era urban China. The American Journal of Sociology 101(4): 950-992. doi: $10.1086 / 230785$.

$\mathrm{Xu}, \mathrm{X} ., \mathrm{Ji}$, J., and Tung, Y. (2000). Social and political assortative mating in urban China. Journal of Family Issues 21(1): 47-77. doi:10.1177/019251300021001003. 
$\mathrm{Xu}, \mathrm{X}$. and Whyte, M. (1990). Love matches and arranged marriages: A Chinese replication. Journal of Marriage and the Family 52(3): 709-722. doi:10.2307/352936.

Yang, D.T. (1997). Education and off-farm work. Economic Development and Cultural Change 45(3): 613-632. doi:10.1086/452293.

Zhang, J., Liu, P., and Yung, L. (2007). The Cultural Revolution and returns to schooling in China: Estimates based on twins. Journal of Development Economics 84(2): 631-639. doi:10.1016/j.jdeveco.2006.12.006.

Zhang, J., Zhao, Y., Park, A., and Song, X. (2005). Economic returns to schooling in urban China, 1988 to 2001. Journal of Comparative Economics 33(4): 730. doi:10.1016/j.jce.2005.05.008.

Zhao, Y. (1997). Labor migration and returns to rural education in China. American Journal of Agricultural Economics 79(4): 1278-1287. doi:10.2307/1244284.

Zhao, Y. (1999). Labor migration and earnings differences: The case of rural China. Economic Development and Cultural Change 47(4): 767-782. doi:10.1086/452431.

Zhao, W. and Zhou, X. (2007). Returns to education in China's transitional economy: Reassessment and reconceptualization. In: Hannum, E. and Park, A. (eds.). Education and Reform in China. Oxford: Routledge.

Zhou, X., Moen, P., and Tuma, N.B. (1998). Educational stratification in urban China: 1949-1994. Sociology of Education 71(3): 199-222. doi:10.2307/2673202.

Zhou, X. (2000). Economic transformation and income inequality in urban China: Evidence from panel data. The American Journal of Sociology 105(4): 11351174. doi:10.1086/210401. 
Appendix 1: Number of observations in pooled sample with six cohorts for women age 15-49 in China

\begin{tabular}{lrrrrr}
\hline Cohorts & \multicolumn{2}{c}{ Rural } & Urban & \\
& Census & Survey & Census & Survey & Total \\
\hline $1970-1974$ & 15,646 & 1,476 & 4,293 & 206 & 21,621 \\
$1975-1979$ & 20,471 & 3,111 & 6,230 & 739 & 30,551 \\
$1980-1984$ & 27,126 & 4,782 & 10,861 & 1,719 & 44,488 \\
$1985-1989$ & 33,763 & 5,683 & 11,134 & 1,874 & 52,454 \\
$1990-1994$ & 28,697 & 4,756 & 9,449 & 1,625 & 44,527 \\
$1995-2001$ & 25,117 & 4,677 & 9,964 & 1,676 & 41,434 \\
Total & 150,820 & 24,485 & 51,931 & 7,839 & 235,075 \\
\hline
\end{tabular}

Source: China Population Census 2000 and Demographic Reproductive Health Survey 2001 


\section{Appendix 2: Odds ratios of educational homogamy relative to intermarriages crossing adjacent educational category among six cohorts for women age $15-49$ in China}

\begin{tabular}{|c|c|c|c|}
\hline \multirow[b]{2}{*}{ Marriage cohorts } & \multicolumn{3}{|c|}{ National } \\
\hline & Illiterate/elementary & Elementary/Jr.High & Jr.High/Sr.High+ \\
\hline $1970-1974$ & 10.51 & 5.74 & 1.75 \\
\hline $1975-1979$ & 12.57 & 5.69 & 1.44 \\
\hline $1980-1984$ & 10.47 & 5.06 & 1.30 \\
\hline $1985-1989$ & 13.79 & 5.30 & 1.80 \\
\hline $1990-1994$ & 18.50 & 5.90 & 2.10 \\
\hline $1995-2001$ & 16.73 & 6.33 & 2.59 \\
\hline Marriage cohorts & Illiterate/elementary & $\begin{array}{c}\text { Rural } \\
\text { Elementary/Jr.High }\end{array}$ & Jr.High/Sr.High+ \\
\hline $1970-1974$ & 10.94 & 6.55 & 0.86 \\
\hline $1975-1979$ & 12.72 & 5.11 & 1.12 \\
\hline $1980-1984$ & 10.83 & 4.50 & 1.11 \\
\hline $1985-1989$ & 14.26 & 4.91 & 1.35 \\
\hline $1990-1994$ & 19.48 & 5.40 & 1.38 \\
\hline \multirow[t]{2}{*}{$1995-2001$} & 17.92 & 5.87 & 1.63 \\
\hline & \multicolumn{2}{|r|}{ Urban } & Sr.High/College+ \\
\hline $1970-1974$ & 3.99 & 3.52 & 1.34 \\
\hline $1975-1979$ & 5.21 & 3.66 & 1.13 \\
\hline $1980-1984$ & 7.85 & 3.62 & 1.56 \\
\hline $1985-1989$ & 7.25 & 4.13 & 2.36 \\
\hline $1990-1994$ & 7.78 & 4.46 & 2.26 \\
\hline $1995-2001$ & 8.86 & 4.62 & 2.45 \\
\hline
\end{tabular}

